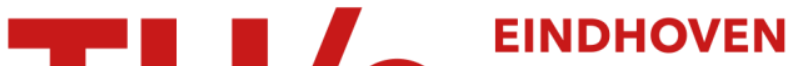 \\ UNIVERSITY OF \\ TECHNOLOGY
}

\section{Propagation of electrical activity in uterine muscle during pregnancy}

Citation for published version (APA):

Rabotti, C., \& Mischi, M. (2015). Propagation of electrical activity in uterine muscle during pregnancy: A review. Acta Physiologica, 213(2), 406-416. https://doi.org/10.1111/apha.12424

DOI:

10.1111/apha.12424

Document status and date:

Published: 01/02/2015

Document Version:

Accepted manuscript including changes made at the peer-review stage

Please check the document version of this publication:

- A submitted manuscript is the version of the article upon submission and before peer-review. There can be important differences between the submitted version and the official published version of record. People interested in the research are advised to contact the author for the final version of the publication, or visit the $\mathrm{DOI}$ to the publisher's website.

- The final author version and the galley proof are versions of the publication after peer review.

- The final published version features the final layout of the paper including the volume, issue and page numbers.

Link to publication

\section{General rights}

Copyright and moral rights for the publications made accessible in the public portal are retained by the authors and/or other copyright owners and it is a condition of accessing publications that users recognise and abide by the legal requirements associated with these rights.

- Users may download and print one copy of any publication from the public portal for the purpose of private study or research.

- You may not further distribute the material or use it for any profit-making activity or commercial gain

- You may freely distribute the URL identifying the publication in the public portal.

If the publication is distributed under the terms of Article $25 \mathrm{fa}$ of the Dutch Copyright Act, indicated by the "Taverne" license above, please follow below link for the End User Agreement:

www.tue.nl/taverne

Take down policy

If you believe that this document breaches copyright please contact us at:

openaccess@tue.nl

providing details and we will investigate your claim. 


\title{
REVIEW \\ Propagation of electrical activity in uterine muscle during pregnancy: a review
}

\author{
C. Rabotti and M. Mischi \\ Electrical Engineering Department, Eindhoven University of Technology, Eindhoven, the Netherlands
}

Received 23 June 2014, revision requested 13 August 2014

revision received 6 November 2014

accepted 7 November 2014

Correspondence: C. Rabotti, PhD,

Eindhoven University of

Technology - Electrical

Engineering, Den Dolech 2,

Eindhoven $5612 \mathrm{AZ}$,

the Netherlands.

E-mail: c.rabotti@tue.nl

\begin{abstract}
The uterine muscle (the myometrium) plays its most evident role during pregnancy, when quiescence is required for adequate nourishment and development of the foetus, and during labour, when forceful contractions are needed to expel the foetus and the other products of conception. The myometrium is composed of smooth muscle cells. Contraction is initiated by the spontaneous generation of electrical activity at the cell level in the form of action potentials. The mechanisms underlying uterine quiescence during pregnancy and electrical activation during labour remain largely unknown; as a consequence, the clinical management of preterm contractions during pregnancy and inefficient uterine contractility during labour remains suboptimal. In an effort to improve clinical management of uterine contractions, research has focused on understanding the propagation properties of the electrical activity of the uterus. Different perspectives have been undertaken, from animal and in vitro experiments up to clinical studies and dedicated methods for non-invasive parameter estimation. A comparison of the results is not straightforward due to the wide range of different approaches reported in the literature. However, previous studies unanimously reveal a unique complexity as compared to other organs in the pattern of uterine electrical activity propagation, which necessarily needs to be taken into consideration for future studies to be conclusive. The aim of this review is to structure current variegated knowledge on the properties of the uterus in terms of pacemaker position, pattern, direction and speed of the electrical activity during pregnancy and labour.

Keywords conduction velocity, pregnancy, electrohysterography, myometrium, smooth muscle, uterine electromyography.
\end{abstract}

Although intermittently active throughout the whole reproductive life of a woman, for instance, during the menstrual cycle, the uterus exerts its most evident function during pregnancy and labour. During pregnancy, quiescence of the uterus is required to maintain pregnancy and allow adequate nourishment and development of the foetus. Towards the end of pregnancy, the uterus becomes increasingly contractile and reactive to excitatory agents until it eventually reaches a state in which it expels the foetus and other products of conception. This contractile state (labour) is achieved when contractions of different regions become stronger, more frequent, and synchronous (Norwitz \& Robinson 2001). Coordination of these contractions is believed to be required for normal progression of parturition (Garfield \& Maner 2007). While some mild uterine activity can always be present during pregnancy without posing any risk for the 
progress of gestation, painful uterine contractions presenting before completing the 37 th week of gestation in a coordinated and forceful fashion can be the first threat of a preterm delivery (Norwitz \& Robinson 2001). Preterm delivery still represents a leading cause of infant mortality and long-term morbidity and, despite major efforts to develop dedicated interventions, it remains difficult to predict and prevent (Garfield et al. 1998, Norwitz \& Robinson 2001, Goldenberg et al. 2008).

The contractile element of the uterus is the myometrium, which is composed of smooth muscle cells. A mechanical contraction is initiated, similarly to other muscle tissues, by the generation of electrical activity at the cell level (Marshall 1962, Garfield et al. 1977, Garfield et al. 1987, Kao 1989, Miller et al. 1989). Although other complementary signalling mechanisms have been postulated (Young \& Hession 1996, 1997) and experiments revealed a possible role of mechanotransduction, that is functional interaction by mechanical mechanisms, in uterine coordination at the organ level (Young 2011), propagation of electrical activity in the form of action potentials is unanimously accepted as the basic mechanism responsible for force production, at least at the tissue level (Marshall 1962, Garfield et al. 1977, Garfield et al. 1987, Kao 1989, Miller et al. 1989). Nevertheless, the exact mechanism underlying uterine quiescence during pregnancy and myometrial electrical activation during labour remains largely unknown (Lammers 2013).

In an effort to improve the clinical management of uterine contractions during pregnancy and labour, significant attention has been dedicated to the electrical activity of the uterus as the primary cause of contractions and to the analysis of the associated signal, referred to as electrohysterogram (EHG) (Figueroa et al. 1987, Maul et al. 2003, Rabotti et al. 2008b, Jacod et al. 2010, Rooijakkers et al. 2014a). Noteworthy, although the term EHG is commonly used to distinguish measurement of uterine electrical signal from the electromyogram (EMG), its counterpart signal recorded in skeletal muscles, some authors still refer to it as uterine EMG, especially for invasive measurements (Devedeux et al. 1993, Lucovnik et al. 2011 b,a). Several investigators have recently turned to understanding the propagation of the uterine electrical activity and elucidated its role in the onset of labour (Rabotti et al. 2009, Lucovnik et al. 2011b, Lammers 2013, de Lau et al. 2013a, de Lau et al. 2014). Different perspectives have been undertaken, from animal and in vitro experiments up to clinical studies and dedicated methods for parameter estimation (Devedeux et al. 1993, Rabotti et al. 2010b). Due to the wide range of different approaches reported in the literature, a comparison of the results is not straightforward.
Nevertheless, previous studies unanimously reveal a unique complexity in the pattern of uterine electrical activity propagation, which necessarily needs to be taken into consideration for future studies to be conclusive.

The aim of this review is to integrate current knowledge on the properties of electrical activity propagation during pregnancy and labour. A number of extensive review papers have been published on uterine electrical activity, addressing the underlying anatomy and physiology (Csap 1959, Csapo 1962, Devedeux et al. 1993, Wray et al. 2001, Maul et al. 2003, Blanks et al. 2007, Lammers 2013), as well as its potential clinical role (Garfield et al. 1998, Garfield \& Maner 2007, Vinken et al. 2009, Lucovnik et al. 2011a). With the aim of quantifying some reference physiological parameters, for example the speed of electrical activity propagation, and providing to future research some general indications for the study design, previous works based on electrophysiological measurements of the uterus during pregnancy are reviewed focusing on the methodological aspects. As the cellular electrophysiology underlying uterine contractility is reviewed in depth in another contribution of this issue by S. Wray et al., we only briefly touch the physiological background and concentrate on aspects related to pacemaker activity, pattern of propagation and propagation speed.

\section{Pacemaker}

During pregnancy, uterine contractions are characterized by a slow cyclic pattern of bursts of action potentials followed by a period of quiescence (Marshall 1962, Kleinhaus \& Kao 1969, Kao 1989, 1959). The uterus is a myogenic organ, which means that, the myometrium is able to contract without nervous or hormonal inputs (Wray 1993, Shmygol et al. 2007) and the electrical activity is controlled by changes in the membrane potential of the smooth muscle cell (Kuriyama \& Suzuki 1976, Ohya \& Sperelakis 1989, Wray 1993). Slow variations in the membrane potential preceding the action potential, called pre-potential, similar to that of the cardiac sinus node (Marshall 1962), are responsible for periods of alternating quiescence and activity (Marshall 1962, Kleinhaus \& Kao 1969, Lammers et al. 1994). However, it is not clear yet whether an exact pacemaker mechanism exists and whether pacemaker activity concerns only dedicated cells or areas.

In some types of smooth muscle, such as gastrointestinal (Sanders 2000) and urethra (Sergeant et al. 2000), a specialized type of cells called interstitial cells of Cajal (ICC) have been found, that constitute a pacemaking mechanism. ICC-like cells have recently 
been found in the human and rat myometrium (Ciontea et al. 2005), but a clear functional role for these cells remains elusive (Duquette et al. 2005).

In order to gain understanding of the electrical activity underlying uterine contractions, many studies focused on locating the pacemaker area of the uterine muscle. Experiments in the isolated preterm pregnant rat myometrium revealed a dominant pacemaker area at the ovary side of the preparation (Lammers et al. 1994). By identifying pacemaker activity with the characteristic pre-potential, specific pacemaker areas of $2 \times 4 \mathrm{~mm}$ where found in the isolated uterus of the pregnant rat (Lodge \& Sproat 1981). In isolated fibres of the rat uterus under the dominant effect of oestrogen, slightly smaller pacemaker areas (2$3 \mathrm{~mm}^{2}$ ) were found near the mesenteric attachment of the uterus (Marshall 1962). During labour, the ovarian end of the horn was the dominant pacemaker area in the rat (Fuchs \& Poblete 1970), and often, contractions have been found to start in the uterine fundus (Caldeyro-Barcia \& Alvarez 1952, Fuchs 1969). However, uterine pacemakers have been mostly observed to arise at random throughout the tissue and change location during the course of a single contraction or several successive contractions also in labour (Marshall 1959, Kuriyama 1961, Parkington et al. 1988, Lammers et al. 1994).

\section{Pattern of propagation}

The functional basis of contractions at the cellular level is the action potential. Action potentials in the myometrium occur in fast sequences referred to as bursts. When studying electrical activity propagation in the myometrium, it is important to differentiate the propagation of a burst from the propagation of single action potentials (also referred to as spikes in electrophysiological recordings) as different mechanisms underpin the two phenomena.

Studies on the propagation of the uterine electrical busts on women in labour reveal, similar to the propagation of the pressure wave (Caldeyro-Barcia \& Alvarez 1952), a predominantly downward propagation and a preferred origin of the burst in the upper/ovarian region of the uterus in women as well as in the guinea-pig (Planes et al. 1984, Norwitz et al. 1999, Lammers et al. 2008, Rabotti et al. 2009, Mikkelsen et al. 2013). However, in women, upward and multidirectional propagation patterns, including simultaneous upward and downward propagation, have also been frequently reported while analysing the myometrial electrical burst (Rabotti et al. 2009, Mikkelsen et al. 2013, Lange et al. 2014). Analysis of the centre of uterine activity, obtained by a Gaussian fitting of the spatial distribution of the burst energy along a two-dimensional grid of electrodes, revealed that women who delivered successfully vaginally, in contrast to those who had arrested labour, had a predominant upward direction of the uterine activity centre (Buhimschi 2009, Euliano et al. 2009).

Recent clinical studies suggest that the propagation of single spikes is more relevant to the prediction of labour than the analysis of the whole burst (Lucovnik et al. 2011b). Before labour and in the uterus of nonpregnant females, inhomogeneous conduction and spontaneous variations in the speed and direction of propagation of individual action potentials within a burst may play a key role in avoiding forceful and coordinated contractions (Melton \& Saldivar 1964, Miller et al. 1989, Lammers et al. 1994, Lammers 1997).

Within a burst, a progressive recruitment phenomenon has been described for individual spikes, that is, the area excited by a spike progressively enlarges within the burst, as evidenced by the number of activated electrodes (see Fig. 1). Using a two-dimensional high-density grid, progressive recruitment was observed in the isolated preterm rat myometrium (Lammers et al. 1994) and in the intact guinea-pig uterus at term, where, on average, it took $22.9 \pm 12.6 \mathrm{~s}$ for the front to excite about $10 \mathrm{~cm}^{2}$ (Lammers et al. 2008). At the end of the burst, the reverse of the recruitment phenomenon can also be observed (Lammers et al. 1994). Progressive recruitment has been reported by studies on rat uterine strips only in the axial direction preterm and not at term when an array of six extracellular glass-pore surface electrodes (3 mm apart) was used (Miller et al. 1989). In these experiments, the small surface covered by the electrode array $(15 \mathrm{~mm})$ might not have been sufficient to appreciate progressive recruitment at term. In fact, spikes propagate further and at higher velocity at parturition than during gestation in both axes when evoked by electrical stimulation and in the axial direction when spontaneous activity is observed (Miller et al. 1989). On the other hand, studies on the intact uterus of pregnant ewes using pairs of stainless-steel wires sewn into the myometrium suggest that individual spikes, whether occurring spontaneously or evoked by electrical stimulation, do not propagate among electrodes that are spatially separated over $3 \mathrm{~cm}$ apart along the longitudinal as well as along the circumferential layer of the myometrium (Parkington et al. 1988).

In the myometrium, the propagation of individual spikes is highly unpredictable and variable and, even within the same burst, numerous occasions of abrupt change of direction of propagation and colliding waves have been described (Lammers et al. 1994). As shown in Fig. 1 for the pregnant rat, individual action 

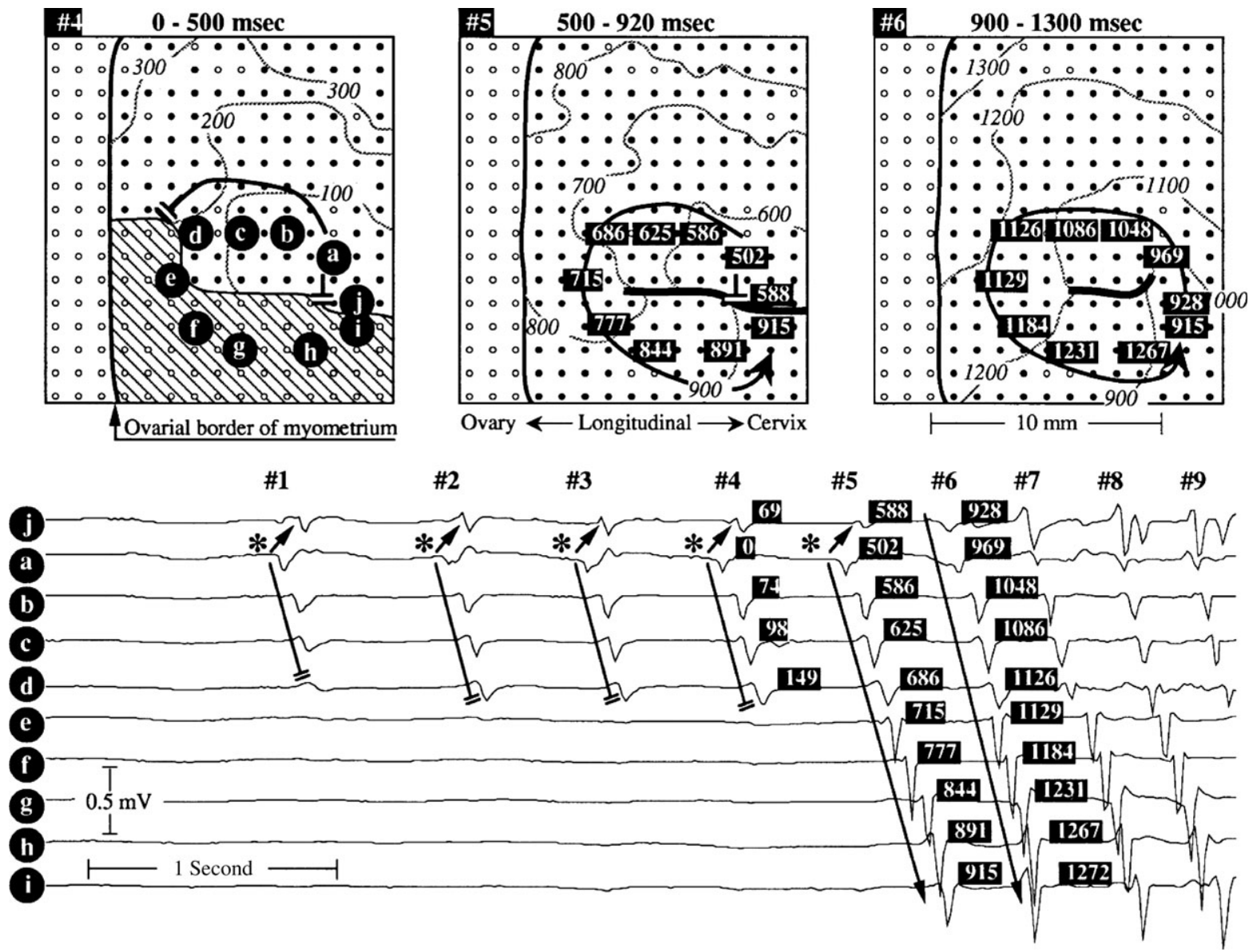

Figure I Example of circular propagation in high-density multi-channel recordings of the isolated pregnant rat myometrium (Lammers 1997). Top panels: propagation maps and local activation times. Numbers indicate which spike of the burst the map refers to. In the top left panel, letters indicate electrodes as reported in the bottom panel. In the top centre and top right panel, the local activation times are indicated at each electrode location. Bottom: time evolution of uterine activity in a selection of electrodes from the grid (indicated by letters). Spikes are numbered progressively as they appear at electrode $j$. At the beginning of the burst, a progressive recruitment phenomenon can also be noticed.

potentials can even propagate spontaneously in a circular fashion similarly to the heart (Lammers 1997, Lammers et al. 2008). While during gestation, circular propagation is not necessarily detrimental (Lammers et al. 1994), it might play a role in premature or dysfunctional labour (Goldenberg et al. 2008, Kao et al. 1989, Lammers 2013, Sergeant 2000).

Regional variations in spike propagation have not been specifically reported with the exception of the placental region, where, in the rat myometrium, weaker potentials, slow propagations, and a shorter length constant were found in microelectrode recordings (Kanda \& Kuriyama 1980). Sparse and fractionated spike propagation was reported in the intact uterus of the guineapig at term (Lammers et al. 2008) along the mesometrial border, where the placenta was located. In the pregnant cat, extracellular recordings showed that the placental region was less excitable and showed little or no spontaneous activity (Daniel \& Renner 1960).

\section{Speed of propagation}

The velocity at which an action potential propagates along a fibre or a tissue is referred to as conduction (or propagation) velocity. In physics, the term velocity usually indicates a vector, identifiable by amplitude and angle. In the myometrium, the direction of conduction velocity is a priory unknown and often, the component of velocity along the connection between the recording electrodes is derived, without identification of the whole velocity vector. To stress that the figures that are reported here are scalar quantities, the term speed of propagation will be used in the following to refer either to projection of the conduction velocity vector on the arbitrary direction connecting two electrodes or on the estimated direction of propagation, depending on the study.

Defining a speed of propagation underlies the assumption that the signal actually propagates 
linearly, which implies that similar signals can be detected at different locations after a certain delay. The literature is not unanimous about the validity of this hypothesis for the myometrium. Due to a lack of evidence, many authors concluded that no classical linear propagation of single action potentials, similar to the myocardium, could be assumed for the myometrium; only propagation of the whole burst could be measured (Duchene et al. 1990, Devedeux et al. 1993) while synchronization of uterine electrical activity should be regarded as non-linear (Hassan et al. 2010, 2013).

Recently, however, an increasing number of studies on animals and women, using high-density grids either placed directly on the uterine surface or on the abdomen, clearly show that also for the myometrium, similar to the myocardium, linear propagation of single electrical spikes occurs and that the speed of propagation can be measured (Lammers 1997, Lammers et al. 1999, 2008, 1994, Rabotti \& Mischi 2010, Lucovnik et al. 2011b).

Table 1 provides an overview of the literature reporting values of propagation speed for single electrical spikes in the uterus during pregnancy. Unless clearly specified, spontaneous activity was measured and unipolar derivation used for the recording electrodes, that is the measured potential was referred to a common electrode placed in a neutral position or far from the electrophysiological source (Van Oosterom 1989).

The propagation speed of electrical spikes in the uterus was for the first time quantified in (Bozler 1938) in longitudinal uterine strips of the guinea-pig, the rabbit and the cat, following an unspecified recording protocol. Slightly higher values than (Bozler 1938) were found in the cat, both in vivo and in vitro, by six to seven wire electrodes (Daniel \& Renner 1960).

On isolated uterine strips of the rat, values of speed in the order of few centimetres were found in the longitudinal layers (Goto et al. 1961, Kanda \& Kuriyama 1980, Miller et al. 1989, Lammers et al. 1999). Lower figures were reported in the circumferential direction (Miller et al. 1989, Lammers et al. 1999) and in the transversal (Lammers et al. 1999), although in the transversal segments estimation of velocity may be complicated by the complex shape and broad peaks of the spikes (Miller et al. 1989). For completeness, it may be interesting to notice that no significantly different figures were found after exposure to oxytocin (Lammers et al. 1999). Still in rats, during the progress of gestation, Kanda \& Kuriyama (1980) observed an increase of propagation speed; as a progressive displacement of the circumferential muscle layer from the placental region was observed, they concluded that motility of this region is mainly controlled by the longitudinal muscle layer (Kanda \& Kuriyama 1980).

Also in the intact uterus of pregnant ewes, Parkington et al. (1988) found that the values of speed in the longitudinal direction significantly increased from preterm to labour. As in (Parkington et al. 1988) an evoked response could not be recorded in more than one pair of the electrodes in the circumferential orientation, the authors concluded that propagation may occur more readily in the longitudinal orientation rather than circumferentially and a consistent direction of propagation could not be found (Parkington et al. 1988). This hypothesis is further reinforced by the higher values found in the longitudinal rather than in the circumferential direction measured by two-dimensional highdensity recordings on the intact uterus of guinea-pigs at term (Lammers et al. 2008).

Speeds in the $1-2 \mathrm{~cm} \mathrm{~s}^{-1}$ range were reported for human muscle strips dissected by biopsies collected during Caesarean sections (Wikland \& Lindblom 1985). On women in labour, using electrodes attached to a catheter and placed in direct contact with the endometrium, from a single bipolar channel, Wolfs \& van Leeuwen (1979) estimated a slightly higher propagation speed assuming biphasic spikes and linear propagation.

High-density measurements for the non-invasive estimation of uterine spike propagation velocity during labour contractions were first described on pregnant women using a two-dimensional flexible grid comprising 64 channels (Rabotti et al. 2010b, Rabotti et al. 2010, Rabotti et al. 2008, de Lau et al. 2013, Mischi et al. 2009, Rabotti et al. 2011). An example of the recording is reported in Fig. 2. for one electrode column. On women in labour, visual selection of spikes leads to average values of propagation speeds similar to those observed in animal experiments (Rabotti et al. 2010b). Aiming at an automatic estimation of myometrial spike propagation velocity for clinical application, using the same high-density grid as in (Rabotti et al. 2010b), analysis of the propagation velocity has been performed in sliding windows. After neglecting propagation speeds above $30 \mathrm{~cm} \mathrm{~s}^{-1}$ in order to exclude artefacts and not propagating activity, values of speed in the same range as by visual spike selection and higher than at preterm were found during labour (de Lau et al. 2013a).

On a larger population of pregnant women, much higher figures of speed than the aforementioned studies have been reported in (Lucovnik et al. 2011b). In this study, however, measurements were performed using only two couples of standard bipolar surface electrodes, that is the active electrode and the reference were close to each other and placed over the 
Table I Overview of previous studies reporting figures of speed for individual electrical spikes in the uterus during pregnancy

\begin{tabular}{|c|c|c|c|c|}
\hline Article & Species & Preparations & Recording method & Speed $\left(\mathrm{cm} \mathrm{s}^{-1}\right)$ \\
\hline Bozler (1938) & $\begin{array}{l}\text { Guinea-pig } \\
\text { Rabbit } \\
\text { Cat }\end{array}$ & $\begin{array}{l}\text { Uterine strips } \\
\text { Longitudinal }\end{array}$ & $\begin{array}{l}\text { Electrical stimulation } \\
\text { Unspecified } \\
\text { recording details }\end{array}$ & $\begin{array}{l}\text { Guinea-pig: } 0.1-0.3 \mathrm{~cm} \mathrm{~s}^{-1} \\
\text { Rabbit: } 1 \mathrm{~cm} \mathrm{~s}^{-1} \\
\text { Cat: } 6 \mathrm{~cm} \mathrm{~s}^{-1}\end{array}$ \\
\hline $\begin{array}{l}\text { Daniel \& } \\
\text { Renner } \\
(1960)\end{array}$ & $\begin{array}{l}\text { Cat (pregnancy } \\
\text { and labour) }\end{array}$ & $\begin{array}{l}\text { In vivo: implanted } \\
\text { electrodes } \\
\text { In vitro: uterine } \\
\text { strips }\end{array}$ & $\begin{array}{l}\text { 6/7 electrodes } \\
\text { In vivo: } 1 \mathrm{~mm} \\
\text { diameter } \\
\text { In vitro: } 0.2 \mathrm{~mm}\end{array}$ & $\begin{array}{l}\text { In vivo: } 9-10 \mathrm{~cm} \mathrm{~s}^{-1} \\
\text { In vitro: } 8-12 \mathrm{~cm} \mathrm{~s}^{-1}\end{array}$ \\
\hline $\begin{array}{l}\text { Goto et al. } \\
\text { (1961) }\end{array}$ & $\begin{array}{l}\text { Rat } \\
\text { (pregnancy) }\end{array}$ & Uterine strips & $\begin{array}{l}\text { Intracellular } \\
\text { microelectrodes }\end{array}$ & $10.2 \pm 0.41 \mathrm{~cm} \mathrm{~s}^{-1}$ \\
\hline \multirow[t]{2}{*}{$\begin{array}{l}\text { Miller et al. } \\
(1989)\end{array}$} & $\begin{array}{l}\text { Rat } \\
\text { (pregnancy) }\end{array}$ & $\begin{array}{l}\text { Uterine strips } \\
\text { Spontaneous and } \\
\text { electrical } \\
\text { stimulation }\end{array}$ & $\begin{array}{l}6 \text { glass-pore surface } \\
\text { electrodes } \\
3 \mathrm{~mm} \text { distance }\end{array}$ & $\begin{array}{l}\text { Longitudinal, spontaneous: } 7.9 \pm 3.0 \mathrm{~cm} \mathrm{~s}^{-1} \\
\text { Longitudinal, stimulation: } 9.2 \pm 0.8 \mathrm{~cm} \mathrm{~s}^{-1} \\
\text { Circumferential, stimulation: } \\
2.3 \pm 0.7 \mathrm{~cm} \mathrm{~s}^{-1}\end{array}$ \\
\hline & Rat (labour) & $\begin{array}{l}\text { Uterine strips } \\
\text { Spontaneous and } \\
\text { electrical } \\
\text { stimulation }\end{array}$ & $\begin{array}{l}6 \text { glass-pore surface } \\
\text { electrodes } \\
3 \mathrm{~mm} \text { distance }\end{array}$ & $\begin{array}{l}\text { Longitudinal, spontaneous: } 13.5 \pm 4.2 \mathrm{~cm} \mathrm{~s}^{-1} \\
\text { Longitudinal, stimulation: } 10.5 \pm 1.3 \mathrm{~cm} \mathrm{~s}^{-1} \\
\text { Circumferential, stimulation: } \\
4.0 \pm 0.8 \mathrm{~cm} \mathrm{~s}^{-1}\end{array}$ \\
\hline \multirow[t]{2}{*}{$\begin{array}{l}\text { Kanda \& } \\
\text { Kuriyama } \\
(1980)\end{array}$} & $\begin{array}{l}\text { Wister/King } \\
\text { rats }\end{array}$ & $\begin{array}{l}\text { Uterine strips } \\
\text { Non-placental } \\
\text { region } \\
\text { Electrical } \\
\text { stimulation }\end{array}$ & $\begin{array}{l}\text { Glass } \\
\text { microelectrodes }\end{array}$ & $\begin{array}{l}\text { Longitudinal, } 7 \text { days gestational age }(\mathrm{GA}) \text { : } \\
6.6 \pm 2.2 \mathrm{~cm} \mathrm{~s}^{-1} \\
\text { Longitudinal, } 15 \text { days GA: } \\
12.3 \pm 3.2 \mathrm{~cm} \mathrm{~s}^{-1} \\
\text { Longitudinal, } 22 \text { days GA: } \\
33.4 \pm 4.1 \mathrm{~cm} \mathrm{~s}^{-1}\end{array}$ \\
\hline & & $\begin{array}{l}\text { Uterine strips } \\
\text { Placental region } \\
\text { Electrical } \\
\text { stimulation }\end{array}$ & $\begin{array}{l}\text { Glass } \\
\text { microelectrodes }\end{array}$ & $\begin{array}{l}\text { Longitudinal, } 15 \text { days GA: } 1.3 \pm 0.4 \mathrm{~cm} \mathrm{~s}^{-1} \\
\text { Longitudinal, } 22 \text { days GA:2.0 } \pm 0.9 \mathrm{~cm} \mathrm{~s}^{-1}\end{array}$ \\
\hline $\begin{array}{l}\text { Parkington } \\
\text { et al. (1988) }\end{array}$ & $\begin{array}{l}\text { Ewe } \\
\text { (pregnancy } \\
\text { and labour) }\end{array}$ & Intact uterus & $\begin{array}{l}\text { Wire bipolar } \\
\text { electrodes } \\
3 \mathrm{~mm} \text { apart } \\
1-2-3 \mathrm{~cm} \text { from } \\
\text { stimulation }\end{array}$ & $\begin{array}{l}\text { Longitudinal, pregnancy: } 7.2 \pm 0.3 \mathrm{~cm} \mathrm{~s}^{-1} \\
\text { Longitudinal, labour: } 13.3 \pm 0.7 \mathrm{~cm} \mathrm{~s}^{-1}\end{array}$ \\
\hline $\begin{array}{l}\text { Lammers } \\
\text { et al. (1999) }\end{array}$ & Rats & $\begin{array}{l}\text { Serosal surface of } \\
\text { dissected segments }\end{array}$ & $\begin{array}{l}240(15 \times 16) \\
\text { electrodes }- \\
0.3 \mathrm{~mm} \text { diameter } \\
1 \mathrm{~mm} \text { distance }\end{array}$ & $\begin{array}{l}\text { Longitudinal: } 4.9 \mathrm{~cm} \mathrm{~s}^{-1} \\
\text { Oblique: } 3.2 \mathrm{~cm} \mathrm{~s}^{-1} \\
\text { Circumferential: } 2.6 \mathrm{~cm} \mathrm{~s}^{-1}\end{array}$ \\
\hline $\begin{array}{l}\text { Lammers } \\
\text { et al. }(2008)\end{array}$ & $\begin{array}{l}\text { Guinea-pig (at } \\
\text { term) }\end{array}$ & Intact uterus & $\begin{array}{l}240(10 \times 24) \\
\text { electrodes } \\
0.3 \mathrm{~mm} \text { diameter } \\
2 \mathrm{~mm} \text { distance }\end{array}$ & $\begin{array}{l}\text { Longitudinal: } 6.8 \pm 2.4 \mathrm{~cm} \mathrm{~s}^{-1} \\
\text { Circumferential: } 2.8 \pm 1.0 \mathrm{~cm} \mathrm{~s}^{-1}\end{array}$ \\
\hline $\begin{array}{l}\text { Wikland \& } \\
\text { Lindblom } \\
(1985)\end{array}$ & $\begin{array}{l}\text { Human } \\
\text { (labour) }\end{array}$ & $\begin{array}{l}\text { Biopsies of the } \\
\text { myometrium }\end{array}$ & $\begin{array}{l}2 \text { suction electrodes } \\
1 \mathrm{~cm} \text { distance }\end{array}$ & Range: $1-2 \mathrm{~cm} \mathrm{~s}^{-1}$ \\
\hline $\begin{array}{l}\text { Wolfs \& van } \\
\text { Leeuwen } \\
(1979)\end{array}$ & $\begin{array}{l}\text { Human } \\
\text { (labour) }\end{array}$ & Intra-uterine & $\begin{array}{l}\text { Two platinum poles } \\
2 \mathrm{~mm} \text { diameter } \\
1 \mathrm{~cm} \text { distance }\end{array}$ & Range: $2.5-5 \mathrm{~cm} \mathrm{~s}^{-1}$ \\
\hline $\begin{array}{l}\text { Rabotti et al. } \\
\text { (2010b) }\end{array}$ & $\begin{array}{l}\text { Human } \\
\text { (Labour) }\end{array}$ & $\begin{array}{l}\text { Abdominal } \\
\text { Selected spikes }\end{array}$ & $\begin{array}{l}64 \text { electrodes } \\
(8 \times 8) \\
1 \mathrm{~mm} \text { diameter } \\
4 \mathrm{~mm} \text { distance }\end{array}$ & $\begin{array}{l}\text { Vertical: } 3.68 \pm 3.24 \mathrm{~cm} \mathrm{~s}^{-1} \\
\text { Horizontal: } 3.76 \pm 3.21 \mathrm{~cm} \mathrm{~s}^{-1} \\
\text { Speed range: } 0.5-13 \mathrm{~cm} \mathrm{~s}^{-1}\end{array}$ \\
\hline $\begin{array}{l}\text { de Lau et al. } \\
\text { (2013a) }\end{array}$ & $\begin{array}{l}\text { Human } \\
\text { (pregnancy } \\
\text { and labour) }\end{array}$ & $\begin{array}{l}\text { Abdominal } \\
\text { Automatically } \\
\text { selected segments }\end{array}$ & $\begin{array}{l}64 \text { electrodes } \\
1 \mathrm{~mm} \text { diameter } \\
4 \mathrm{~mm} \text { distance }\end{array}$ & $\begin{array}{l}\text { Pregnancy: } 5.30 \pm 1.47 \mathrm{~cm} \mathrm{~s}^{-1} \\
\text { Labour: } 8.65 \pm 1.90 \mathrm{~cm} \mathrm{~s}^{-1}\end{array}$ \\
\hline $\begin{array}{l}\text { Lucovnik } \\
\text { et al. (2011b) }\end{array}$ & $\begin{array}{l}\text { Human } \\
\text { (pregnancy) }\end{array}$ & $\begin{array}{l}\text { Abdominal } \\
\text { Selected spikes }\end{array}$ & $\begin{array}{l}2 \text { bipolar leads } \\
2.5 \mathrm{~cm} \text { distance }\end{array}$ & $\begin{array}{c}\text { Delivery within } 7 \text { days: } 52.56 \pm 33.94 \mathrm{~cm} \mathrm{~s}^{-1} \\
\text { Delivery after } 7 \text { days: } 11.11 \pm 5.13 \mathrm{~cm} \mathrm{~s}^{-1}\end{array}$ \\
\hline
\end{tabular}




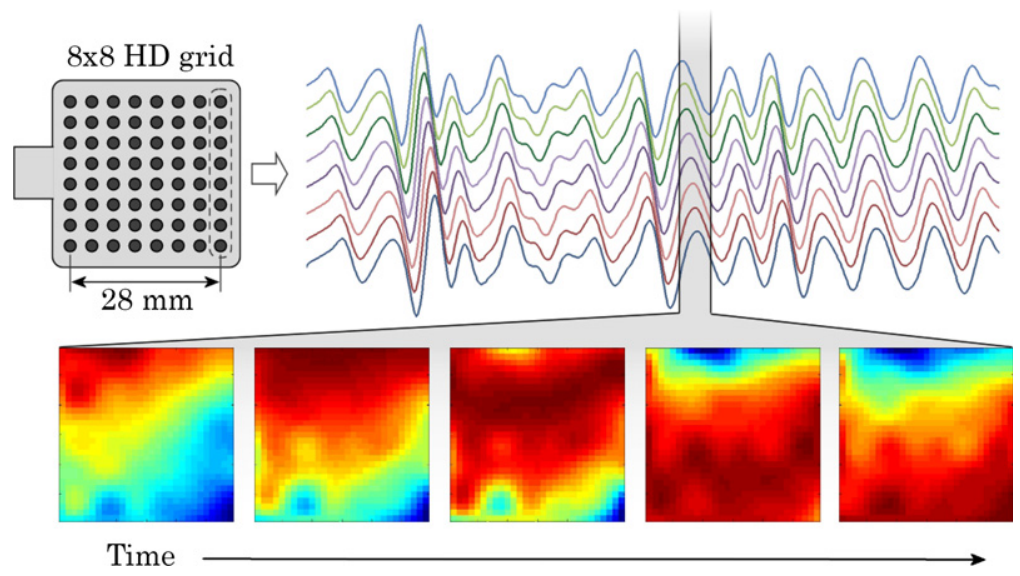

Figure 2 High-density (HD) grid measurements on women in labour. Schematic representation and dimensions of the squared electrode grid (top left). Colour-coded propagation map in the selected time interval (bottom) and burst of electrical activity in a selected column of the grid (top right). Each map represents the electrical signal recorded by the grid in a certain moment in time. The colour is proportional to the signal intensity (red indicates high intensity, blue indicates low intensity) in the corresponding electrode in the grid (de Lau et al. 2013a). For smoother visualization, amplitude values derived from contiguous electrodes have been interpolated (Rabotti et al. 2010b).

abdomen. Such high values of speed, which cannot be attributed to artefacts or not propagating activity due to the prior visual selection of the spikes, could be due to the unknown origin and direction of signal propagation. In fact, the speed calculated by only two electrodes is just the component of the velocity vector along the direction indicated by the line connecting the two electrodes (Wolfs \& van Leeuwen 1979, Rabotti et al. 2011b).

Overall, relative to single spike propagation, lower speed figures have been reported for the whole burst (Lammers et al. 2008). For the burst, high-density recording directly on the intact uterus of guinea-pigs at term lead to values of $0.6 \pm 0.4 \mathrm{~cm} \mathrm{~s}^{-1}$ (Lammers et al. 2008). In humans, non-invasive measurements of burst propagation during delivery using two electrodes placed $6 \mathrm{~cm}$ apart led to values equal to $2.18 \pm 0.98 \mathrm{~cm} \mathrm{~s}^{-1}$ (Planes et al. 1984). Values of speed with the same average and similar variability, equal to $0.68 \mathrm{~cm} \mathrm{~s}^{-1}$, have been found using a twodimensional 16-channel grid in six women in active labour at term (Lange et al. 2014). On a comparable number of subjects in labour, eight channel recordings also lead to estimated values of burst propagation speed in the $4-5 \mathrm{~cm} \mathrm{~s}^{-1}$ range (Rabotti et al. 2009). By analysing separately the upper and the lower uterine segment, Mikkelsen et al. found similar average values equal to 2.15 and $1.53 \mathrm{~cm} \mathrm{~s}^{-1}$, but with a higher variability, between 0.66 and $13.8 \mathrm{~cm} \mathrm{~s}^{-1}$ and between 0.58 and $6.7 \mathrm{~cm} \mathrm{~s}^{-1}$, for the upper and lower uterine segment respectively (Mikkelsen et al. 2013). In this study, three electrodes were placed along the central medial axis of the abdomen and the centre of mass of the EHG burst envelop was used as reference for the calculation of the interchannel delay (Mikkelsen et al. 2013).

\section{Concluding remarks}

Extensive research has focused on understanding the electrical activity of the uterus and its propagation properties in different species and under different conditions. In this review of the literature, we focus on previous works based on electrophysiological measurements of the uterus during pregnancy and concentrate on aspects related to pacemaker activity, pattern of propagation and propagation speed.

Although thoroughly investigated in a number of studies, location and mechanisms of pacemaker activity are not understood both during pregnancy and at term. Propagation of electrical activity in the uterus does not show a preferential direction; it seems instead characterized by a highly unpredictable and potentially complex propagation pattern of individual spikes (Lammers et al. 1994, 2008). Interestingly, calcium events measured in strips of myometrium have been shown to spread and be as chaotic as the electrical activity that they are reflecting (Burdyga et al. 2009). Less erratic patterns have been described for the whole electrical burst, although simultaneous upward and downward propagation have been frequently reported (Rabotti et al. 2009, Mikkelsen et al. 2013, Lange et al. 2014).

There is evidence that conduction of electrical activity gradually improves as gestation progresses (Miller et al. 1989). The basis of conduction of electrical 
activity in the uterus lies in the cell-to-cell coupling by gap junctions (Garfield et al. 1977). We could speculate that the increased number of gap junctions observed prior to labour in many species plays a role in the improved conduction of electrical activity and could be reflected in higher conduction speeds towards the end of gestation (Garfield et al. 1987). The speed at which the spikes within a burst propagate in the myometrium can therefore be a key parameter for the distinction between pregnancy and labour contractions, possibly supporting the diagnosis of preterm labour (Lucovnik et al. 2011b, Rabotti et al. 2011a, de Lau et al. 2013b). However, the literature is not unanimous about the occurrence of linear electrical propagation in the myometrium and, therefore, the possibility of measuring propagation velocity. Considering the recording methods of the studies supporting the possibility of measuring linear propagation (Lammers et al. 1994, 2008, 1999, Lammers 1997, Rabotti \& Mischi 2010, Rabotti et al. 2010b, Lucovnik et al. 2011b) and of those that failed measuring it (Duchene et al. 1990, Devedeux et al. 1993), we may conclude that only small interelectrode distances allow for recording a linear propagation of electrical spikes. Universally defining an optimal electrode distance for recording spike propagation is however complicated, as it might be highly dependent on the species (Kuriyama \& Suzuki 1976, Wikland \& Lindblom 1985), on the type of recording (Lammers et al. 1994, Rooijakkers et al. 2014b), on the placenta location (Kanda \& Kuriyama 1980) and, in case of external abdominal recordings, on the properties of the volume conductor (Rabotti et al. 2010a, Laforet et al. 2011).

In the vast majority of reviewed studies which reported conduction speed measurements unipolar derivations were used. In fact, although bipolar measurements provide a better signal-to noise ratio, due to the a priori unknown pacemaker region and direction of propagation, unipolar recordings should be preferred for the analysis of electrical propagation in the uterus (Rabotti et al. 2007, 2008a, Hassan et al. 2011). Being the myometrium a smooth muscle, values of propagation speed in the order of few centimetres per second could be expected (Devedeux et al. 1993). While the majority of the reviewed studies, independently on the investigated species, reports figures in this range (Bozler 1938, Daniel \& Renner 1960, Goto et al. 1961, Wolfs \& van Leeuwen 1979, Kanda \& Kuriyama 1980, Wikland \& Lindblom 1985, Parkington et al. 1988, Miller et al. 1989, Lammers et al. 1999, Lammers et al. 2008, de Lau et al. 2013a), higher values have also been measured (Lucovnik et al. 2011b). Defining a reference physiological range for the propagation speed is therefore difficult.
Literature seems to agree that propagation occurs more rapidly in the longitudinal direction and more slowly in the transversal and circumferential ones (Miller et al. 1989, Lammers et al. 1994). Anisotropy was also occasionally observed in circular propagation and re-entries (Miller et al. 1989, Lammers et al. 1994, Lammers 1997). In general, it should be kept in mind that when recording on the whole organ or on the abdomen, interactions between the longitudinal and circumferential layers of the myometrium may easily affect the overall conduction pattern (Lammers et al. 1994). However, anisotropy alters the radial pattern of propagation and the isochrones around the pacemaker area follow an ellipsoidal pattern rather than a circular one (Lammers et al. 1994). As a consequence, the position of the sensor grid relative to the pacemaker location plays an important role in the correct reconstruction of the propagation pattern as predominantly longitudinal or transversal (Lammers et al. 1994).

Noteworthy, when the direction of propagation is $a$ priori unknown, the actual physical value of speed can be derived only by prior identification of origin and direction of electrical propagation. For example, when only two electrodes are used, the origin of electrical propagation should be external and its direction parallel to the line connecting the two electrodes (Lammers et al. 2008, Rabotti et al. 2011b). Although it is expected to be less critical for burst propagation analysis than for spike analysis due to the less erratic propagation pattern, this constraint is generally valid for analysing the propagation of burst as well as of single spikes. Many authors analysed the conduction properties of the myometrium separately in the axial and circumferential directions (Miller et al. 1989). However, in general, for the analysis of myometrial spikes, two-dimensional multi-channel recordings are expected to provide a more accurate description of propagation.

In this review, the propagation of electrical activity has been mainly analysed in two dimensions. Although with classical electrophysiological measurements it is not immediate to extend the analysis to the third dimension, it should be kept in mind that propagation of electrical activity in the myometrium involves functional interactions in the three dimensions. Moreover, mechanical phenomena such as changes in uterine wall thickness during contractions and respiration-induced uterine wall movements can affect the interpretation of the uterine electrical activity recorded on the abdomen and should therefore be taken into account (de Lau et al. 2013b, Rabotti et al. 2013). Finally, mathematical modelling of uterine electrical activity, especially when approached on a multi-scale point of view and empirically validated, 
can significantly contribute to increase knowledge on the link between non-invasive measurements, the underlying physiology and the onset of labour and to ensure reliable measurement by dedicated artefact modelling and removal (Rihana et al. 2009, Aslanidi et al. 2011, Laforet et al. 2011, Rabotti et al. 2013, Sharp et al. 2013).

In conclusion, analysis of the electrical propagation in the uterus offers a unique opportunity to understand the mechanisms underlying uterine contractility and may open the way to significant improvements in the management of pregnancy and labour. However, previous literature on the uterus unanimously reveals a special complexity of its electrical propagation properties; this poses specific challenges for the measurement and use of the uterine electrical features and further studies are therefore necessary to clarify the potential role of the EHG in clinical practice.

\section{Conflict of interest}

The authors state that there is no conflict of interest concerning the research work carried out for this manuscript.

This work was funded by the Dutch technology foundation, STW (grant nr 12472).

\section{References}

Aslanidi, O., Atia, J., Benson, A.P., van den Berg, H., Blanks, A.M., Choi, C., Gilbert, S., Goryanin, I., Hayes-Gill, B. \& Holden, A.V. 2011. Towards a computational reconstruction of the electrodynamics of premature and full term human labour. Prog Biophys Mol Biol 107, 183-192.

Blanks, A.M., Shmygol, A. \& Thornton, S. 2007. Myometrial function in prematurity. Best Pract Res Clin Obstet Gynaecol 21, 807-819.

Bozler, E. 1938. The action potentials of visceral smooth muscle. Am J Physiol 124, 502-510.

Buhimschi, C.S. 2009. Spatiotemporal electromyography during human labor to monitor propagation of the uterine contraction wave and diagnose dystocia. Am J Obstet Gynecol 200, 1-3.

Burdyga, T., Borisova, L., Burdyga, A.T. \& Wray, S. 2009. Temporal and spatial variations in spontaneous $\mathrm{Ca}$ events and mechanical activity in pregnant rat myometrium. Eur J Obstet Gynecol Reprod Biol 144, S25-S32.

Caldeyro-Barcia, R. \& Alvarez, H. 1952. Abnormal uterine action in labour. J Obstet Gynaecol Br Emp 59, 646.

Ciontea, S.M., Radu, E., Regalia, T., Ceafalan, L., Cretoiu, D., Gherghiceanu, M., Braga, R., Malincenco, M., Zagrean, L. \& Hinescu, M. 2005. C-kit immunopositive interstitial cells (Cajal-type) in human myometrium. J Cell Mol Med 9, 407420.

Csap, A. 1959. Function and regulation of the myometriuum. Ann N Y Acad Sci 75, 790-808.
Csapo, A. 1962. Smooth muscle as a contractile unit. Physiol Rev Suppl 5, 7-33.

Daniel, E. \& Renner, S. 1960. Effect of the placenta on the electrical activity of the cat uterus in vivo and in vitro. Am J Obstet Gynecol 80, 229-244.

Devedeux, D., Marque, C., Mansour, S., Germain, G. \& Duchene, J. 1993. Uterine electromyography: a critical review. Am J Obstet Gynecol 169, 1636-1653.

Duchene, J., Marque, C. \& Planque, S. 1990. Uterine EMG signal: propagation analysis. Conf Proc IEEE Eng Med Biol Soc, 1990, 831-832.

Duquette, R.A., Shmygol, A., Vaillant, C., Mobasheri, A., Pope, M., Burdyga, T. \& Wray, S. 2005. Vimentin-positive, c-kit-negative interstitial cells in human and rat uterus: a role in pacemaking? Biol Reprod 72, 276-283.

Euliano, T.Y., Marossero, D., Nguyen, M.T., Euliano, N.R., Principe, J. \& Edwards, R.K. 2009. Spatiotemporal electrohysterography patterns in normal and arrested labor. Am J Obstet Gynecol 200, 54.e1-54. e7.

Figueroa, J., Massmann, A., Pimentel, G. \& Nathanielsz, P. 1987. Characteristics of the electromyogram recorded from the mesometrium of the pregnant ewe from 106 days' gestation to delivery: similarities with and differences from the electromyogram obtained from the myometrium. Am J Obstet Gynecol 157, 991-998.

Fuchs, A.-R. 1969. Uterine activity in late pregnancy and during parturition in the rat. Biol Reprod 1, 344-353.

Fuchs, A.-R. \& Poblete, V.F. 1970. Oxytocin and uterine function in pregnant and parturient rats. Biol Reprod 2, $387-400$.

Garfield, R.E. \& Maner, W.L. 2007. Physiology and electrical activity of uterine contractions. Semin Cell Dev Biol 18, 289-295.

Garfield, R., Sims, S. \& Daniel, E. 1977. Gap junctions: their presence and necessity in myometrium during parturition. Science 198, 958-960.

Garfield, R., Blennerhassett, M. \& Miller, S. 1987. Control of myometrial contractility: role and regulation of gap junctions. Oxf Rev Reprod Biol 10, 436-490.

Garfield, R., Saade, G., Buhimschi, C., Buhimschi, I., Shi, L., Shi, S. \& Chwalisz, K. 1998. Control and assessment of the uterus and cervix during pregnancy and labour. Hum Reprod Update 4, 673-695.

Goldenberg, R.L., Culhane, J.F., Iams, J.D. \& Romero, R. 2008. Epidemiology and causes of preterm birth. Lancet 371, 75-84.

Goto, M., Kuriyama, H. \& Abe, Y. 1961. Refractory period and conduction of excitation in the uterine muscle cells of the mouse. Jpn J Physiol 11, 369.

Hassan, M., Terrien, J., Alexandersson, A., Marque, C. \& Karlsson, B. 2010. Nonlinearity of EHG signals used to distinguish active labor from normal pregnancy contractions. Conf Proc IEEE Eng Med Biol Soc, 2010, 2387-2390.

Hassan, M., Boudaoud, S., Terrien, J., Karlsson, B. \& Marque, C. 2011. Combination of canonical correlation analysis and empirical mode decomposition applied to denoising the labor electrohysterogram. IEEE Trans Biomed Eng 58, 2441-2447.

Hassan, M., Terrien, J., Muszynski, C., Alexandersson, A., Marque, C. \& Karlsson, B. 2013. Better pregnancy 
monitoring using nonlinear correlation analysis of external uterine electromyography. IEEE Trans Biomed Eng 60, $1160-1166$.

Jacod, B.C., Graatsma, E.M., van Hagen, E. \& Visser, G.H. 2010. A validation of electrohysterography for uterine activity monitoring during labour. J Matern Fetal Neonatal Med 23, 17-22.

Kanda, S. \& Kuriyama, H. 1980. Specific features of smooth muscle cells recorded from the placental region of the myometrium of pregnant rats. J Physiol 299, 127-144.

Kao, C.Y. 1959. Long-term observations of spontaneous electrical activity of the uterine smooth muscle. Am J Physiol 196, 343-350.

Kao, C. 1989. Electrophysiological properties of uterine smooth muscle. Biology of the Uterus. Springer, New York, USA.

Kleinhaus, A. \& Kao, C. 1969. Electrophysiological actions of oxytocin on the rabbit myometrium. J Gen Physiol 53, 758-780.

Kuriyama, H. 1961. Recent studies on the electrophysiology of the uterus. Ciba Found Study Group 9, 51-70.

Kuriyama, H. \& Suzuki, H. 1976. Changes in electrical properties of rat myometrium during gestation and following hormonal treatments. J Physiol 260, 315-333.

Laforet, J., Rabotti, C., Terrien, J., Mischi, M. \& Marque, C. 2011. Toward a multiscale model of the uterine electrical activity. IEEE Trans Biomed Eng 58, 3487-3490.

Lammers, W.J.E.P. 1997. Circulating excitations and re-entry in the pregnant uterus. Eur J Physiol 433, 287-293.

Lammers, W.J.E.P. 2013. The electrical activities of the uterus during pregnancy. Reprod Sci 20, 182-189.

Lammers, W.J., Arafat, K., El-Kays, A. \& El-Sharkawy, T.Y. 1994. Spatial and temporal variations in local spike propagation in the myometrium of the 17-day pregnant rat. Am J Physiol 267, c1210-c1223.

Lammers, W.J.E.P., Stephen, B., Hamid, R. \& Harron, D.W.G. 1999. The effects of oxytocin on the pattern of electrical propagation in the isolated pregnant uterus of the rat. Pflügers Archiv - Eur J Physiol 437, 363-370.

Lammers, W.J.E.P., Mirghani, H., Stephen, B., Dhanasekaran, S., Wahab, A., Al Sultan, M.A.H. \& Abazer, F. 2008. Patterns of electrical propagation in the intact pregnant guinea pig uterus. Am J Physiol Regul Integr Comp Physiol 294, R919-R928.

Lange, L., Vaeggemose, A., Kidmose, P., Mikkelsen, E., Uldbjerg, N. \& Johansen, P. 2014. Velocity and directionality of the electrohysterographic signal propagation. PLoS ONE 9, e86775.

de Lau, H., Rabotti, C., Bijloo, R., Rooijakkers, M.J., Mischi, M. \& Oei, S.G. 2013a. Automated conduction velocity analysis in the electrohysterogram for prediction of imminent delivery: a preliminary study. Comput Math Methods Med 2013, 7.

de Lau, H., Rabotti, C., Haazen, N., Oei, S.G. \& Mischi, M. 2013b. Towards improving uterine electrical activity modeling and electrohysterography: ultrasonic quantification of uterine movements during labor. Acta Obstet Gynecol Scand 92, 1323-1326. de Lau, H., Rabotti, C., Oosterbaan, H.P., Mischi, M. \& Oei, S.G. 2014. Study protocol: PoPE-Prediction of Preterm delivery by Electrohysterography. BMC Pregnancy Childbirth 14, 192.

Lodge, S. \& Sproat, J.E. 1981. Resting membrane potentials of pacemaker and non pacemaker areas in rat uterus. Life Sci 28, 2251-2256.

Lucovnik, M., Kuon, R.J., Chambliss, L.R., Maner, W.L., Shi, S.Q., Shi, L., Balducci, J. \& Garfield, R.E. 2011a. Use of uterine electromyography to diagnose term and preterm labor. Acta Obstet Gynecol Scand 90, 150-157.

Lucovnik, M., Maner, W.L., Chambliss, L.R., Blumrick, R., Balducci, J., Novak-Antolic, Z. \& Garfield, R.E. 2011b. Noninvasive uterine electromyography for prediction of preterm delivery. Am J Obstet Gynecol 204, 228.e1228.e10.

Marshall, J.M. 1959. Effects of estrogen and progesterone on single uterine muscle fibers in the rat. Am J Physiol 197, 935-942.

Marshall, J.M. 1962. Regulation of activity in uterine smooth muscle. Physiol Rev Suppl 5, 213-227.

Maul, H., Maner, W.L., Saade, G.R. \& Garfield, R.E. 2003. The physiology of uterine contractions. Clin Perinatol 30, 665-676.

Melton, C.E. \& Saldivar, J.T. 1964. Impulse velocity and conduction pathways in rat myometrium. Am J Physiol 207, 279-285.

Mikkelsen, E., Johansen, P., Fuglsang-Frederiksen, A. \& Uldbjerg, N. 2013. Electrohysterography of labor contractions: propagation velocity and direction. Acta Obstet Gynecol Scand 92, 1070-1078.

Miller, S.M., Garfield, R.E. \& Daniel, E.E. 1989. Improved propagation in myometrium associated with gap junctions during parturition. Am J Physiol 256, C130-C141.

Norwitz, E.R. \& Robinson, J.N. 2001. A systematic approach to the management of preterm labor. Semin Perinatol 25, 223-235.

Norwitz, E.R., Robinson, J.N. \& Challis, J.R.G. 1999. The control of labor. N Engl J Med 341, 660-666.

Ohya, Y. \& Sperelakis, N. 1989. Fast Na+ and slow Ca2+ channels in single uterine muscle cells from pregnant rats. Am J Physiol 257, C408-C412.

Parkington, H.C., Harding, R. \& Sigger, J.N. 1988. Co-ordination of electrical activity in the myometrium of pregnant ewes. J Reprod Fertil 82, 697-705.

Planes, J., Morucci, J., Grandjean, H. \& Favretto, R. 1984. External recording and processing of fast electrical activity of the uterus in human parturition. Med Biol Eng Compu 22, 585-591.

Rabotti, C. \& Mischi, M. 2010. Two-dimensional estimation of the electrohysterographic conduction velocity. Conf Proc IEEE Eng Med Biol Soc, 2010, 4262-4265.

Rabotti, C., Mischi, M., van Laar, J., Oei, G. \& Bergmans, J. 2007. Electrohysterographic analysis of uterine contraction propagation with labor progression: a preliminary study. Conf Proc IEEE Eng Med Biol Soc 2007, 4135-4138.

Rabotti, C., Mischi, M., Van Laar, J., Oei, G. \& Bergmans, J. 2008a. On the propagation analysis of electrohystero- 
graphic signals. Conf Proc IEEE Eng Med Biol Soc, 2008, 3868-3871.

Rabotti, C., Mischi, M., van Laar, J.O.E.H., Oei, G.S. \& Bergmans, J.W.M. 2008b. Estimation of internal uterine pressure by joint amplitude and frequency analysis of electrohysterographic signals. Physiol Meas 29, 829-841.

Rabotti, C., Mischi, M., van Laar, J.O.E.H., Oei, G.S. \& Bergmans, J.W.M. 2009. Inter-electrode delay estimators for electrohysterographic propagation analysis. Physiol Meas 30, 745-761.

Rabotti, C., Mischi, M., Beulen, L., Oei, G. \& Bergmans, J.W.M. 2010a. Modeling and identification of the electrohysterographic volume conductor by high-density electrodes. IEEE Trans Biomed Eng 57, 519-527.

Rabotti, C., Mischi, M., Oei, S.G. \& Bergmans, J.W.M. 2010b. Noninvasive estimation of the electrohysterographic action-potential conduction velocity. IEEE Trans Biomed Eng 57, 2178-2187.

Rabotti, C., Bijloo, R., Oei, G. \& Mischi, M. 2011a. Vectorial analysis of the electrohysterogram for prediction of preterm delivery: a preliminary study. Conf Proc IEEE Eng Med Biol Soc 2011, 3880-3883.

Rabotti, C., Oei, S.G., Van 'T Hooft, J. \& Mischi, M. 2011b. Comment to electrohysterographic propagation velocity for preterm delivery prediction. Am J Obstet Gynecol 205, e9-e10.

Rabotti, C., De Lau, H., Haazen, N., Oei, G. \& Mischi, M. 2013. Ultrasound analysis of the uterine wall movement for improved electrohysterographic measurement and modeling. Conf Proc IEEE Eng Med Biol Soc 2013, 7436-7439.

Rihana, S., Terrien, J., Germain, G. \& Marque, C. 2009. Mathematical modeling of electrical activity of uterine muscle cells. Med Biol Eng Compu 47, 665-675.

Rooijakkers, M.J., Rabotti, C., Oei, S.G., Aarts, R.M. \& Mischi, M. 2014a. Low-complexity intrauterine pressure estimation using the Teager energy operator on electrohysterographic recordings. Physiol Meas 35, 1215-1228.

Rooijakkers, M.J., Song, S., Rabotti, C., Oei, S.G., Bergmans, J.W., Cantatore, E. \& Mischi, M. 2014b. Influence of electrode placement on signal quality for ambulatory pregnancy monitoring. Comput Math Methods Med, 2014, 12.
Sanders, K.M. 2000. Postjunctional electrical mechanisms of enteric neurotransmission. Gut 47, iv23-iv25.

Sergeant, G.P., Hollywood, M.A., McCloskey, K., Thornbury, K. \& McHale, N. 2000. Specialised pacemaking cells in the rabbit urethra. J Physiol 526, 359-366.

Sharp, G., Saunders, P. \& Norman, J. 2013. Computer models to study uterine activation at labour. Mol Hum Reprod 19, 709-710.

Shmygol, A., Blanks, A.M., Bru-Mercier, G., Gullam, J.E. \& Thornton, S. 2007. Control of uterine Ca2+ by membrane voltage. Ann N Y Acad Sci 1101, 97-109.

Van Oosterom, A. 1989. Lead systems for the abdominal fetal electrocardiogram. Clin Phys Physiol Meas 10, 21.

Vinken, M.P.G.C., Rabotti, C., Mischi, M. \& Guid Oei, S. 2009. Accuracy of frequency-related parameters of the electrohysterogram for predicting preterm delivery: a review of the literature. Obstet Gynecol Surv 64, 529-541.

Wikland, M. \& Lindblom, B. 1985. Relationship between electrical and mechanical activity of the isolated term-pregnant human myometrium. Eur J Obstet Gynecol Reprod Biol 20, 337-346.

Wolfs, G.M.J.A. \& van Leeuwen, M. 1979. Electromyographic observations on the human uterus during labour. Acta Obstet Gynecol Scand 58, 1-61.

Wray, S. 1993. Uterine contraction and physiological mechanisms of modulation. Am J Physiol Cell Physiol 264, C1-C18.

Wray, S., Kupittayanant, S., Shmygol, A., Smith, R.D. \& Burdyga, T. 2001. The physiological basis of uterine contractility: a short review. Exp Physiol 86, 239-246.

Young, R.C. 2011. Mechanotransduction in rat myometrium: coordination of contractions of electrically and chemically isolated tissues. Reprod Sci 18, 64.

Young, R.C. \& Hession, R.O. 1996. Intra-and intercellular calcium waves in cultured human myometrium. $J$ Muscle Res Cell Motil 17, 349-355.

Young, R.C. \& Hession, R.O. 1997. Paracrine and intracellular signaling mechanisms of calcium waves in cultured human uterine myocytes. Obstet Gynecol 90, 928-932. 